Sri Lanka J. Aquat. Sci. 20 (2) (2015): 9-18

\title{
Co-management of the fishery of Senanayake Samudra, a large perennial reservoir in Sri Lanka
}

\author{
W.M.J. Rohitha Fernando, Jayantha Chandrasoma, K.B. Chandrani \\ Pushpalatha* and Mahinda Kulathilaka
}

National Aquaculture Development Authority of Sri Lanka, No.41/1, New Parliament Road, Pelawatte, Battaramulla, Sri Lanka

*Corresponding author (pushpakbc@yahoo.com)

\begin{abstract}
There are about 170,000 ha of perennial reservoirs in Sri Lanka and the inland fisheries of these reservoirs are well documented. The fisheries production in these reservoirs in 2013 was 55,000 tonnes, accounting for about $11.0 \%$ of the total fish production in the country. More than $80 \%$ of the inland fish production comes from medium and major perennial reservoirs (>250 ha.). Procedure existed for reservoir fisheries management was through a centralized management authority and fisher communities were not involved in decision making for management of fisheries.

In 2004, Ministry of Fisheries and Aquatic Resources introduced a strategy to get stakeholders involved for sustainable management of reservoir fisheries. This paper evaluates the effectiveness of the strategy introduced for the fisheries management in Senanayake Samudra (7,793 ha at FSL), the largest perennial reservoir in Sri Lanka.

Introduced strategy for management of the fishery had all ingredients of a comanagement system. Stakeholders were fisheries authorities from the central government, fishers, wildlife authorities and the police. Tasks required for the sustainable management of fisheries were identified through active participation of stakeholders, which in turn were allocated to relevant parties. All stakeholders were consulted in the decision making process aimed at sustainable development. Relevant strategies were formulated in consensus with all stakeholders.

Introduction of co-management to the fishery has resulted in significant decrease in the use of illegal fishing gear as well as unauthorized fishing. Further, direct involvement of members of community-based organization (CBO) resulted in the availability of reliable data on catch and effort. Introduction of management measures facilitated a significant increase in fish production. The process of collective decision making and responsibilities of stakeholders has reduced conflicts and contributed to long term sustainability. Fisher CBO has already observed benefits in the form of increased income due to enhanced fish catches.
\end{abstract}

Keywords: tropical reservoir, rural fishing communities, collective decision. 


\section{Introduction}

Sri Lanka is blessed with large number irrigation reservoirs and most of them are concentrated in the dry zone receiving $125-190 \mathrm{~cm}$ annual rainfall). The total reservoir extent is about 200,000 ha (Jayasinghe and Amarasinghe 2015). Onoverage they range from a few ha to 7,800 ha and depending on their hydrological regimes they are regarded as either perennial or seasonal. These reservoirs, with a few exceptions, are irrigation reservoirs and are very diverse in age, size, hydrology and catchment features (Amarasinghe et al. 2002). Perennial reservoirs (around 170,000 ha) are divided into three broad size categories; large, medium and small depending on the water spread at full supply level.

These irrigation reservoirs have been secondarily used for inland fisheries production. The inland fisheries of Sri Lanka have developed as a result of introduction of exotic species, Oreochromis mossambicus in 1952. Inland fisheries in reservoirs yielded around 55,000 tonnes in 2013, accounting for about $11 \%$ of the total fish production in Sri Lanka. Inland fisheries now provide animal protein at affordable prices, employment, and additional income to rural communities making a very significant contribution to the rural economy. More than $80 \%$ of the inland fish production comes from medium and major perennial reservoirs (>250 ha). These reservoirs are very productive with the average annual yield of about $283 \mathrm{~kg}$ ha $^{-1}$ (De Silva 1988; Fernando 2000). Trends in the inland Fisheries in perennial reservoirs of Sri Lanka are well documented (Mendis 1977; Fernando 1977; De Silva 1988; Chandrasoma 1992; Amarasinghe and Weerakoon 2009). The centralized management of the inland fisheries that prevailed in the country required continuous monitoring of the fisheries which was not cost-effective.

Ministry of Fisheries and Aquatic Resource Development (MoFARD) introduced a co-management strategy to get stakeholders involved in sustainable management of fisheries in major and medium reservoirs under the Aquatic Resource Development and Quality Improvement Project (ARDQIP), funded by Asian Development Bank (Van der Knapp et al. 2007). Co-management has been defined by various authors (Pinkerton 1989; Pomeroy and Williams 1994; Barbosa and Hartman 1998; Carlsson and Berkes 2005), and the features of fisheries comanagement include sharing of responsibilities, rights and duties between the stake holders, organizational development and decision making through community participation. Amarasinghe and De Silva (1999) and Nathanael and Edirisinghe (2002) have shown that introduction of co-management to the reservoir fisheries of Sri Lanka is possible. Under the ARDQIP, attempts were made to introduce comanagement to the fishery of Senanayake Samudra, the largest perennial reservoir in Sri Lanka. This paper evaluates the effectiveness of co-management strategy for the fishery of Senanayake Samudra. 
W.M.J.R. Fernando et al./Sri Lanka J. Aquat. Sci. 20 (2) (2015): 9-18

\section{Materials and Methods}

\section{Senanayake Samudra}

Senanayake Samudra (7,793 ha at full supply level) is situated in the Eastern Province of Sri Lanka. This reservoir was built in the 1940s when a dam was constructed across the Gal Oya River and at present it is the largest reservoir in Sri Lanka. Fernando and Indrasena (1969) described the fishery and morphometry of this reservoir, and accordingly, Senanayake Samudra is a deep reservoir, with a maximum depth of $25 \mathrm{~m}$ at full supply level (FSL), with steeply sloping margins and a very narrow littoral zone. Harvesting of fish in the reservoir is a year round activity. Non-mechanized fibreglass outrigger canoes are used for fishing. Fishing gear used are gillnets with stretched mesh sizes ranging from 8.5 to $20 \mathrm{~cm}$. In general, each canoe is operated by two fishers who place their nets in the evening and haul in the following morning. Van der Knapp et al. (2007) reported that 74 canoes were operated in 2006 by 147 fishers. Senanayake Samudra is situated within a wildlife protection area declared under the Flora and Fauna Protection Ordinance.

\section{Community based organization}

A community based organization (CBO) in the form of a fisheries cooperative society, has been in existence in Senanayake Samnudra since early 1980s. Under the centralized management system that existed until recently, the fishers were compelled to become members of the CBO to get benefits of state-sponsored subsidy schemes through which fisheries authorities provided fishers with fishing canoes, fishing gear and housing facilities. These cooperative societies functioned only until the state-sponsored subsidy scheme lasted. As shown by Amarasinghe and De Silva (1999), this centralized management strategy did not sustain in the fishery of Senanayake Samudra. The status of CBO in the reservoir was observed to be weak, no regular meetings were held, attendance at the meeting had been poor and record keeping in respect of accounts had been inconsistent. CBOs were not involved in decision making process in respect of fisheries management.

\section{Legal framework}

Adequate legal provisions exist under Fisheries and Aquatic Resources Act of 1996 (FAR Act) for the management of inland fisheries. These provisions include registration of fishing craft, need to obtain a license for fishery operations, prevention of the use of fishing gear specified as illegal etc. The requirement to obtain fishing licenses prevents open access to fishing. In addition, there are provisions to limit the number of units of fishing gear (number of gill nets) each inland fisher. Use of gillnets with mesh sizes below $85 \mathrm{~mm}$ is prohibited. Also drag nets, seine nets, mono-filament gillnets and trammel nets are forbidden to be used in reservoir fisheries of Sri Lanka. The use of explosives, sedatives, poisons etc. to kill fish is also prohibited under these regulations. 
Legal foundation for co-management arrangements is also provided under section VI of the FAR Act. These provisions include declaration of certain areas as special areas of management, and facilitation of involvement of fishing communities in fisheries management and decision making.

\section{Government authorities}

State fisheries authorities act as the centralized management authority. Extension officer of the National Aquaculture Development Authority of Sri Lanka was assigned to implement relevant management provisions of the FAR Act. In addition, Extension Officer was responsible for the development of inland fisheries and aquaculture activities in the area, collection of relevant fish production statistics and facilitation of provision of subsidies. Despite the existence of adequate legal framework for management of inland fisheries in Sri Lanka, fisheries in most reservoirs are poorly managed. Use of illegal fishing gear was very rampant and incidences of fishing by unauthorized fishers had been very high. This was mainly due to the reason that the lack of mechanism to get fisher communities involved in fisheries management and decision making through recognition of their vital role. The multitude of reservoirs scattered all over dry zone of the island also has made centralized management system less effective due to the difficulty of monitoring individual fisheries with limited number of extension officers.

\section{Awareness and community consultation}

Officers of ARDQIP together with the Aquaculture Extension Officer assigned to the area conducted meetings with fishers about the resource and its sustainable development, the importance of resource management and role of fishers therein. The potential for development of inland fisheries in reservoirs and the existing laws and regulations related to the inland fisheries in reservoirs were discussed during these meetings. In addition, awareness was created among all government officers in the area. This initial awareness-creation programme lasted for about 4 months.

Participatory rural appraisal (PRA) method (De Silva et al. 2006) was carried out so that $\mathrm{CBO}$ members analyzed their own conditions, suggested solutions and got organized to implement them. CBO members also identified constraints to sustainability of the fishery and possible solutions to overcome them during the exercise.

\section{Stakeholders and allocation of tasks}

Fisheries authorities from the central government, irrigation authorities, local police, fishers and fish vendors were identified as stakeholders. Fishers and fish vendors are members of the fisher CBO. As Senanayake Samudra is situated within a wildlife protection area, the Department of Wildlife Conservation was also treated as an important stakeholder. Tasks required to be performed to ensure sustainable management of inland fisheries were identified with the participation of all stakeholders. 


\section{Management measures}

Formulation of management strategies was essentially a stakeholder consultation in the reservoir. Members of $\mathrm{CBO}$ in the reservoir have got involved actively in making tangible decisions for the management of the fishery. As all stakeholders were involved in the process, the officers of ARDQIP attempted to arrive at a reasonable compromise toward sustainable management of the fishery.

\section{Results}

$\mathrm{CBO}$ members were enthusiastic in the PRA process as they were motivated by the fact that their voice was heard by the fisheries authorities from whom entire support till then was virtually expected as a 'top-down' approach. The existing constraints in the reservoir fishery to its sustainability and potential solutions identified by CBO members are summarized in Table 1 .

Table 1. Constraints to the sustainability of the fishery and potential solutions identified by CBO members through PRA methodology.

\begin{tabular}{ll}
\hline Constraints & Potential solutions \\
\hline $\begin{array}{l}\text { Weak fisher CBO } \\
\text { Rampant use of illegal fishing gear; } \\
\text { unauthorized fishing }\end{array}$ & $\begin{array}{l}\text { Strengthening of fisher CBO } \\
\text { prevent use of illegal fishing gear by } \\
\text { members }\end{array}$ \\
$\begin{array}{l}\text { Lack of coordination among relevant } \\
\text { Government authorities such as } \\
\text { fisheries, wildlife and irrigation }\end{array}$ & $\begin{array}{l}\text { Fisheries authorities together with other } \\
\text { law enforcement authorities to arrest } \\
\text { Fisher CBO in decision making }\end{array}$ \\
$\begin{array}{l}\text { No proper monitoring of fishing/fish } \\
\text { Involvement of relevant Government } \\
\text { agencies }\end{array}$ & $\begin{array}{l}\text { Fisher CBO to actively get involved in } \\
\text { monitoring of fishing and recording fish } \\
\text { catch data }\end{array}$ \\
$\begin{array}{l}\text { Non adequacy of funds to carryout } \\
\text { stocking of fish seed as well as to } \\
\text { implement management measures }\end{array}$ & $\begin{array}{l}\text { Fisher CBO to levy a fee on each kg of } \\
\text { fish landed. }\end{array}$ \\
\hline
\end{tabular}

Details of tasks assigned to different stakeholders during the present study are given in Table 2.

\section{Management measures}

The $\mathrm{CBO}$ in consultation with and consensus of all stakeholders formulated and introduced several management strategies in order to prevent the use of illegal fishing gear and facilitate close monitoring of fisheries and data collection. The recommendations of stakeholders with a reasonable compromise between all parties are summarized in Table 3. 
Table 2. Allocation of tasks among stakeholders.

\begin{tabular}{|c|c|}
\hline Stakeholder & Allocated tasks \\
\hline Fisher CBO & $\begin{array}{l}\text { Preventing the use of illegal fishing gear by CBO } \\
\text { members; collection and maintenance of fish catch data; } \\
\text { sustain stocking of fish fingerlings. }\end{array}$ \\
\hline $\begin{array}{l}\text { Government fisheries } \\
\text { authorities }\end{array}$ & $\begin{array}{l}\text { Implementation of relevant regulations of the Fisheries } \\
\text { and Aquatic Resources Act of } 1996 \text { including the } \\
\text { registration of fishing craft, licensing, prevention of } \\
\text { illegal fishing gears and unauthorized fishing; } \\
\text { strengthening of fisher CBO. }\end{array}$ \\
\hline Local Police & $\begin{array}{l}\text { Police Officers are also authorized to implement } \\
\text { regulations related to prevention of illegal fishing gear } \\
\text { use and unauthorized fishing. }\end{array}$ \\
\hline Wildlife authorities & $\begin{array}{l}\text { Implementation of provisions in the Sri Lanka Flora and } \\
\text { Fauna Protection Ordinance (Chapter 469) to regulate } \\
\text { fishing in Wildlife protected areas; Issue of permits. }\end{array}$ \\
\hline
\end{tabular}

Table 3. The management decisions of the stakeholders for sustainability of the fishery of Senanayaka Samudra.

(i) Fixing of time periods for fishing (2.00 pm. to $9.00 \mathrm{am}$. following day)

(ii) Reduction of number of landing sites from 7 to 1 .

(iii) Fisher CBO members agree to use gillnets with mesh sizes of $102 \mathrm{~mm}$ and above, although the minimum permissible mesh size under the law is $85 \mathrm{~mm}$.

(iv) Carrying out surveillance of the reservoir to prevent unauthorized fishers.

(v) Collection of a levy for each $\mathrm{kg}$ of fish landed from $\mathrm{CBO}$ members, and crediting to a $\mathrm{CBO}$ fund for purchasing of fish fingerlings for stocking and other welfare activities for CBO members.

(vi) Appointment of monitors to the landing site to observe adherence of fishers to the stipulated fishing times, use of illegal fishing gear, weigh catches and maintain records of fish harvest and to collect the levy described in (v) above.

(vii) Introduction of a system for imposing penalties on CBO members, who violate conditions for fishing agreed with other stakeholders.

(viii) $\mathrm{CBO}$ involvement in selling of fish catch of member fishers, instead of following the existing practice of each fisher selling their catch to fish vendors.

(ix) Collection of species-wise fish catch data and maintain in a computerized database.

Co-management strategy was introduced in 2005 and this has resulted in fully committed involvement of fisher $\mathrm{CBO}$ members in the management of the resource. The fisheries resource users were actively involved in decision making through the fisher CBO. All stakeholders have implemented allocated tasks 
satisfactorily to overcome constraints to sustainability of the fishery.

Management measures adopted such as establishment of a single landing site, fixed time duration for fishing, appointment of monitors for the landing site have made fishing more transparent and facilitated significant decrease of the incidence of use of illegal fishing gear. Surveillance of the fishing activities by CBO members resulted in a low incidence of unauthorized fishing. Information provided by $\mathrm{CBO}$ members helped fisheries authorities and the police to carry out raids to apprehend unauthorized fishers. Introduction of management measures including stocking has resulted in significant increase in the fish catch. The following improvements and changes were observed in the fishery of Senanayake Samudra, after introduction of co-management.

(1) Reduction of incidents of use of illegal fishing gear by CBO members; number of incidents reduced to 0 in 2008-2013 from >100 incidents per year during 2000-2005 period.

(2) Number of incidents of unauthorized fishing without a license has reduced to very few $(<5)$ during 2008-2013 from 70-100 incidents per year during 2000-2004 period.

(3) Fish production of the reservoir increased from 97.5 tonnes in 2004 to 614.9 tonnes in 2013. Landing size of Nile tilapia increased from around $250 \mathrm{~g}$ to $>750 \mathrm{~g}$.

(4) Stocking undertaken has resulted in increased contribution of carps in the fish landings. Contribution of carps (mainly catla and rohu) to the total fish catch increased from almost negligible level to around 38\% in 2013.

(5) Fishers actively contributed to recording of very accurate species-wise fish catch data and the fishing effort.

(6) Fishers were able to get a reasonable price for their produce throughout the year, due to undertaking of marketing of fish by the CBO.

(7) Fisher $\mathrm{CBO}$ became very strong and active with highly motivated fisher CBO members, dedicated to achieve objectives. Savings of the fisher CBO increased from around Rs. 200,000 in 2004 to around Rs. 8 million by 2013.

\section{Discussion}

Direct involvement of the $\mathrm{CBO}$ has resulted in the availability of reliable catch and effort statistics pertaining to the reservoirs, which are of importance for making decisions in respect of development of inland fishery, and for evaluating impact of stocking. Availability of such data collected and maintained by the CBO is of importance as a model data recording system in the inland fishery of Sri Lanka, where monitoring of all reservoirs scattered in rural areas in impracticable with very limited number of fisheries officials available.

Co-management is essentially a partnership arrangement where both resource users at the community level and government authorities are involved in the decision making process of resource management (Berkes 1994), which is different from community-based resource management where there is no government involvement. 
Fisher CBO members have experienced financial benefits after implementation of co-management due to enhanced fish catches. This has motivated fisher $\mathrm{CBO}$ members to contribute actively to the co-management. The process of collective decision making and sharing responsibilities among stakeholders have reduced conflicts among fishers and contributed in the long run, to problem solving. Fisher CBO members were very eagerly involved in implementation of assigned tasks. These resulted in making fisher $\mathrm{CBO}$ members more committed towards sustainable fisheries management and develop confidence in the CBO.

Also satisfactory implementation of allocated tasks by other stakeholders is another feature in successful introduction of co-management in the fishery. Management of the fishery of Senanayake Samudra had all the ingredients of a comanagement system viz. power sharing arrangement between the government and resource users, approaches to solve resource management problems by partnership and division of labour through allocation of tasks (Carlsson and Berkes 2005). Pinkerton (1989) has discussed a number of tasks that can easily be accomplished by establishing well-functioning co-management systems such as data gathering, logistical decisions such as who can harvest and when, allocation decisions, protection of resource from environmental damage, enforcement of regulations and enhancement of long-term planning. According to Carlsson and Berkes (2005) division of labour through allocation of tasks enabled specialization to increase efficiency.

Senanayake Samudra has been declared as a special management area under the provisions of FAR Act. Provisions are also available under this act to institutionalize the $\mathrm{CBO}$ working committee as the management authority for a particular reservoir, frame regulations specific to the declared area of management if decided by the $\mathrm{CBO}$ and acceptable to the Minister of Fisheries and Aquatic Resources Development. Accordingly, based on the request of the fisher CBO, Minister of Fisheries and Aquatic Resources Development has published regulations stipulating minimum mesh size of $102 \mathrm{~mm}$ for gill nets and minimum landing size of $250 \mathrm{~g}$ and $1500 \mathrm{~g}$ for tilapia and carps respectively in respect of this reservoir. This case study therefore provides a practical introduction of co-management for the fishery of Senanayake Samudra.

\section{References}

Amarasinghe, U.S. \& S.S. De Silva 1999. Sri Lankan reservoir fishery: a case for introduction of a co-management strategy. Fisheries Management and Ecology 6: 387-399.

Amarasinghe, U.S., S.S. De Silva \& C. Nissanka 2002. Fish yield prediction based on catchment features, quantified using Geographical Information Systems, in lowland reservoirs of Sri Lanka. In: GIS-Spatial Analyses in Fishery and Aquatic Sciences (Volume 2): Proceedings of the Second International Symposium on GIS-Spatial Analyses in Fishery and Aquatic Sciences (University of Sussex, Brighton, UK, 3-6 September 2002), Fishery-Aquatic GIS Research Group, Kawagoe-City, Saitama, Japan, pp. 499-514. 
W.M.J.R. Fernando et al./Sri Lanka J. Aquat. Sci. 20 (2) (2015): 9-18

Amarasinghe, U.S. \& D.E.M. Weerakoon 2009. Present status and future strategies for the management of reservoir fisheries in Sri Lanka. 69-98 pp. In: De Silva, S.S. and U.S. Amarasinghe (eds.), Status of reservoir fisheries in five Asian countries. NACA Monograph No. 2. Network of Aquaculture Centres in Asia-Pacific, Bangkok, Thailand. 116p

Barbosa, F.I. \& W.D. Hartman 1998. Participatory management of reservoir fisheries in north-eastern Brazil. pp. 427-445. In: (T. Petr, ed.) Inland fishery enhancements. Papers presented at the FAO/DFID Expert Consultation on Inland Fishery Enhancements. Dhaka, Bangladesh, 7-11 April 1997. FAO Fisheries Technical Paper No. 374. Food and Agriculture Organization of the United Nations, Rome. 463 p.

Berkes, F. 1994. Co-management: bridging the two solitudes. Northern Perspectives 22: $18-20$.

Berkes, F. 1994. Co-management: bridging the two solitudes. Northern Perspectives 22 (2-3): 18-20.

Carlsson, L. \& F. Berkes 2005. Co-management: concepts and methodological implications. Journal of Environmental Management 75: 65 - 76.

Chandrasoma, J. 1992. Impact of stocking of exotic carp species on the fish production of made-made lakes, in Sri Lanka - A reappraisal. Sri Lanka Journal of Aquatic Sciences 1: $71-80$.

De Silva, S.S. 1988. Reservoirs of Sri Lanka and their fisheries. FAO Fisheries Technical Paper 298: 128 p.

De Silva, S.S., U.S. Amarasinghe \& T.T.T. Nguyen 2006. Better practice approaches for culture based fisheries development in Asia. ACIAR Monograph No. 120: $96 \mathrm{p}$.

Fernando, C.H. 1977. Reservoir fisheries in South East Asia: Past, present and future. Proceeding of Indo-Pacific Fisheries Council 17(3): 475 - 480.

Fernando, C.H. 2000. A view of the inland fisheries of Sri Lanka: Past, present and future. Sri Lanka Journal of Aquatic Sciences 5: 1-26.

Fernando, C.H. \& H.H.A. Indrasena 1969. The freshwater fisheries in Ceylon. Bulletin of the Fisheries Research Station, Ceylon 20: $101-134$.

Jayasinghe, J.M.P.K. \& U.S. Amarasinghe 2015. Inland Aquatic Resources. In: Natural Resources of Sri Lanka: Conditions, Trends and Prospects. National Science Foundation of Sri Lanka, Colombo. pp. 00-00 (in press).

Mendis, A.S. (1977). The role of man-made lakes in the development of fisheries in Sri Lanka. Proceeding of Indo-Pacific Fisheries Council 17(3): 247 - 254.

Nathanael, S. \& U. Edirisinghe 2002. Developing co-management in an artisanal gill net fishery of a deep hydro-electric reservoir in Sri Lanka. Fisheries Management and Ecology 9(5): 267-276.

Pinkerton. E. 1989. Co-operative Management of Local Fisheries: New Directions for Improved Management and Community Development. University of British Colombia Press, Vancouver, British Columbia.

Pomeroy, R.S. \& M.S. Williams 1994. Fisheries co-management and small-scale fisheries: a policy brief. International Centre for Living Aquatic Resources Management, Manila. 15 p. 
W.M.J.R. Fernando et al./Sri Lanka J. Aquat. Sci. 20 (2) (2015): 9-18

Van der Knapp, M., R. Fonseka, N. Andramana \& S. Perera 2007. Report on Frame Survey 2006, Sri Lanka. Ministry of Fisheries and Aquatic Resources. Aquatic Resource Development and Quality Improvement Project. ADB Loan No.1910/1911-SRI. Asian Development Bank, Manila. 